\title{
1. The EU legislative process. An introduction from a political science perspective
}

\section{Doreen Allerkamp}

\section{INTRODUCTION}

The subject matter of this book falls into the realm of what political science describes as 'judicial politics', that is, the perpetual struggle between legislators' intent and enforcers' discretion to shape policy outcomes. While the 'standard assumption' about the 'political role' of the courts - that of a 'separation of powers where courts adjudicate conflicts based on law being legitimated by the legislature' - would not seem to attribute to them 'greater political significance', ${ }^{1}$ this assumption does not allow for the fact that all legislation is inevitably incomplete. It is from this circumstance that case law arises, 'complementing the legal texts of the legislature', and where the 'independent impact' of the interpreters and enforcers of legislation - in this case, the Court of Justice of the European Union (CJEU) - 'becomes apparent' ${ }^{2}$ they can, in filling the gaps, dispose of a certain amount of leeway, which for the CJEU is considerable and 'much larger' than for national courts. ${ }^{3}$ This, however, is only 'part of the explanation' for the Court's 'independent political role': because legislatures are rarely 'capable of acting unequivocally' and in particular that of the EU, which involves (at least) two independently strong institutions which must find a measure of agreement both

1 SK Schmidt, 'The Shadow of Case Law. The Court of Justice of the European Union and the Policy Process', in J Richardson and S Mazey (eds), European Union Power and Policy-Making (Routledge 2015) 159, 161.

2 Ibid., 161.

3 Ibid., 162, cf S Hix and B Høyland, The Political System of the European Union (3rd edn, Palgrave 2011) 75. 
within and between themselves in order to make EU law - a 'legislative override' of CJEU decisions is in most cases hard to come by. ${ }^{4}$

Thus, the core dilemma underlying judicial politics is that between, on the one hand, the need for the rule of law and judicial independence in order to achieve effective law enforcement and, on the other hand, the inevitably resulting judicial discretion that effectively gives the judiciary a role in law-making rather than merely law-enforcement. ${ }^{5}$ Case law not only 'guides the future behaviour of courts', and therefore those subject to the law, but also law-makers, who operate in the shadow of the future: the framing and specification of legislation inevitably anticipates the fact that its interpretation and enforcement is guided by precedent. ${ }^{6}$ To ask about the influence and discretion of the CJEU is to raise the question to what extent accumulating case law constrains EU policymaking, 'given that judicial policy-making is a possible substitute to legislative policy-making'? ${ }^{7}$

This chapter first briefly introduces the main institutions involved in making EU legislation and their major incentives and constraints (II.A), before outlining the EU's main legislative procedure (II.B) with particular attention to the informal trilogue (II.C). The subsequent sections address the CJEU's key role in EU polity-construction (III.A) before focusing on the discussion of its role in the context of EU policy-making (III.B), namely facilitating compliance with (III.B.1) but also shaping EU law (III.B.2), as well as the limits of CJEU discretion (III.B.3).

\section{LAW-MAKING IN THE EU - ACTORS, INCENTIVES AND CONSTRAINTS}

Political science can just about agree that the EU is a 'polity', i.e. a political system of some kind, somewhere between a state and an international organization. Although there have been a plethora of attempts to capture it more precisely, none of them has achieved a degree of consent that warrants the designation 'broadly accepted' - or been meaningful enough to be truly controversial. The EU is many things to many people. Moreover, it is not a static political system that has (been) completed (in) a process of teleological development and thus could easily be compared to other obvious examples of the species. Rather, it is

\footnotetext{
Schmidt (fn. 1) 161.

Hix and Høyland (fn. 3) 78.

Schmidt (fn. 1) 161.

Ibid., 160.
} 
constantly evolving, without any clearly definable finality. ${ }^{8}$ While many purposes and goals are and have over time been associated with the EU by a variety of stake-holders, its development - the process of European integration - has been a lot more evolutionary than predictable or even intentional. Similarly, while many individual aspects of the EU, such as the quality of its legitimacy, its institutions, its output or the processes by which it produces it, readily lend themselves to comparisons with others or assessment by pre-existing standards, the EU as a whole remains very much sui generis.

\section{A. The EU's Key Legislative Institutions - Incentives and Constraints}

The EU's legislative process is a particular case in point. Political responsibility for EU legislation is not borne by a government or some other consolidated authority; rather, it is distributed among several institutions, each legitimated in a different way and each with a distinct role to play in the making of EU law. Decisive in this context are the Council, the Parliament and the Commission, as well as - though it is conventionally defined as the core of the EU's judiciary, not its legislature - the CJEU, which will be considered separately below. ${ }^{9}$ The interrelationships among the Council, the Commission and the Parliament are complex, and their incentives, constraints and relative influence over legislative outcomes are governed by the cumulative effect of a variety of formal and informal rules and norms. The latter two - supranational institutions' formal legislative influence has been growing, and while it still varies by policy area, in 'most areas of regulatory policy-making' they play a large role, ${ }^{10}$ because the majority of secondary EU law, including the 2014 Public Procurement Package, now falls under the 'Ordinary Legislative Procedure' (OLP), in which all three collaborate to

8 Indeed, the negotiations to avert 'Brexit' in early 2016 provided a clear demonstration of divergent preferences over the finality of European integration and the purpose of the EU.

9 On the CJEU, see section III. Both the Commission and the Council have, beyond their legislative roles, executive functions, which will not be considered here; in addition, the European Council of Member States' heads of state and/or government, while it explicitly 'shall not exercise legislative functions' (Art. 15 TEU), can also affect legislative outcomes in various ways, most notably through its overall role in the political leadership of the EU.

10 R Thomson, 'The Distribution of Power Among the Institutions', in Richardson and Mazey (eds) (fn. 1) 189, 195. 
create new legislation. ${ }^{11}$ Nevertheless, "most analysts would agree that the Council is the centre of power in the EU', while the Commission has 'considerable power particularly during the formative stages of the policymaking process' and the Parliament 'punches at least somewhat below the weight it is ascribed in the formal procedures.' 12

The Council is the main stronghold of 'the most powerful actors in the EU system - the Member States' governments.' ${ }^{13}$ It is 'still the prime legislative institution of the EU - no legislation is passed without the consent of the Council', even if 'it has had to get used to sharing legislative power' with the Parliament 'on most issues'. ${ }^{14}$ Both 'intergovernmental and supranational in its procedures', it is also 'both national and European in its interests and incentives': ${ }^{15}$ on the one hand, it is the forum for the representation of Member States' diverse interests in the EU, where national envoys at all levels of the Council hierarchy from bureaucrats in technical working groups through professional diplomats in the Committee of Permanent Representatives (COREPER) to government ministers in the Council (and heads of state in the European Council) - are pursuing national preferences in dealing with the EU's agenda. On the other hand, the Council is the scene of the continuous negotiation of compromises among Member States, a process aided and abetted by the rotating Council Presidency, the Council Secretariat and a host of informal norms fostering agreement, since the Council's role in EU law-making requires a unified Council position in order to engage with the other EU institutions. Thus, while the Member States' incentive is to maximize their respective national preferences regarding the regulation of public procurement, they are restrained by the need to compromise in order to arrive at a common Council position. In turn, the Council's overall incentive is to maintain the Member States' prerogatives by defending its position, while it is restrained by the need to find agreement with the Parliament in order to produce legislation.

For its part, the Parliament brings together the elected representatives of the citizens of the EU and is the location of party-political, as opposed to international, clashes over issues on the EU's agenda. However, the link between voters and their members of Parliament is 'weak', given

11 Cf. Art. 294 TFEU. The OLP currently applies in 85 Treaty-defined policy areas, i.e. most of the EU's substantive areas of competence.

12 Thomson (fn. 10) 205.

13 D Naurin, 'The Councils of the EU. Intergovernmental Bargaining in a Supranational Polity', in Richardson and Mazey (eds) (fn. 1) 135, 136.

14 Ibid., 136.

15 Ibid. 
that the latter 'face a dilemma' in having to cater, on the one hand, to their national parties 'to secure re-selection and re-election' and, on the other hand, to their political group leaderships and committees in the Parliament 'to secure promotion ... and policy outputs' there. ${ }^{16}$ While the parliamentarians therefore normally 'try to avoid upsetting their political group leaderships', if they are 'ever torn between their national party and their European political group, they almost always vote with their national party', but also 'more along transnational party lines than national lines' ${ }^{17}$ Because there is no EU government relying on steady majority support in the Parliament, it is 'a relatively independent legislature, free to amend legislation proposed by the Commission and agreed by the Council, and the Commission and the Council must build coalitions in the Parliament issue by issue'. ${ }^{18}$ Consequently, on 'many' issues the Parliament 'behaves as if it were a single actor seeking to promote its own powers and interests' against those of the other two legislative institutions. ${ }^{19}$ The rules of the legislative process enable 'an informal "grand coalition" "between the two largest factions, ${ }^{20}$ which 'secures the pro-integrationist stand' the Parliament takes in these 'interinstitutional battles', while the internal 'day-to-day ideological battle between left and right' mirrors that of most national parliaments: 'In sum, the leaders of the main political groups balance the need to present a united front against the Council and the Commission and the need to present competing ideological alternatives for the future of the EU.'21 Thus, just like the Council and, to a lesser extent, the Commission, the Parliament faces an internal balancing act. But two aspects weaken the relative strength of the Parliament vis-à-vis the Council. First, while its

16 Hix and Høyland (fn. 3) 54-5.

17 Ibid., 57 and 60. Cf, inter alia, A Kreppel, 'What Affects the European Parliament's Legislative Influence? An Analysis of the Success of EP Amendments' (1999) 37(3) Journal of Common Market Studies 521.

18 Hix and Høyland (fn. 3) 54.

19 Ibid., 59.

20 While a simple majority of those present suffices to win a vote on opinions, own initiative reports and amendments to resolutions on legislation, an absolute majority of all members of Parliament is required for amendments in OLP second reading ( $c f$ section II.B). Thus, coalition formation is 'at least partly shaped' by which majority is needed: the two largest groups, currently the Christian Democrats (EPP) and the Social Democrats (S\&D), are able to form winning coalitions 'with various combinations of smaller groups' for a simple majority, but for an absolute majority, it is 'almost impossible' to do so without both of them. Hix and Høyland (fn. 3) 59-60.

21 Hix and Høyland (fn. 3) 60. 
powers have been 'gradually extended over the past decades' in successive Treaty reforms cumulating in the normalization of co-decision in the OLP by the Lisbon Treaty, it is still 'excluded from legislative co-decision' in wide policy areas including welfare, taxation, and foreign policy. ${ }^{22}$ Second, the requirement of an absolute majority to amend or reject a bill in second reading puts the Parliament 'at a disadvantage', because it makes it 'easier' for it 'to accept the common position of the Council than to reject or amend it'. ${ }^{23}$ Thus, a comparison of different procedural (focusing on formal rules) and bargaining (including informal rules) models of EU decision-making shows that the Parliament's 'actual ability to affect legislation' is less than expected, and the notion of it as 'co-equal legislator' under the OLP must be 'qualified' ${ }^{24}$

As the third main player in EU law-making, the Commission is tasked with representing the interest of the Union, and its formal role consists mainly of its monopoly on legislative proposals and the subsequent implementation and monitoring of the resulting EU legislation. It also contributes to the formation of both the Council's and the Parliament's respective positions, and plays a role in the negotiation of legislation between them. Because '[i]ts institutional position in the EU's political system demands the Commission ... come up with an EU-wide binding policy-proposal', ${ }^{25}$ it can be argued that it has 'a strategic incentive' to avoid its proposals failing, to the extent that it 'will refrain from tabling a proposal in the first place if it does not anticipate that it will gain enough support' from the other two legislative institutions. ${ }^{26}$ Moreover, it can be 'compelled' by the Member States or the Parliament to introduce

22 B Rittberger and T Winzen, 'The EU's Multilevel Parliamentary System', in J Richardson and S Mazey (eds) (fn. 1) 107, 110.

23 Hix and Høyland (fn. 3) 69. Cf S Hagemann and B Høyland, 'Bicameral Politics in the European Union' (2010) 48(4) Journal of Common Market Studies 811. They also found that in the bicameral bargaining between Council and Parliament, each chamber's cohesiveness made a difference, as the Parliament is less likely to find the absolute majority required in second reading to amend the common position of a divided Council than that of a unified Council, which points to 'a close connection between the political parties represented across the institutions', Hix and Høyland (fn. 3) 73.

24 Rittberger and Winzen (fn 22) 111. Cf R Thomson, Resolving Controversy in the European Union. Inputs, Processes and Outputs in Legislative Decision-Making before and after Enlargement (Cambridge University Press 2011).

25 A Wonka, 'The European Commission', in J Richardson and S Mazey (eds) (fn. 1) 83, 100.

26 Naurin (fn. 13) 145 and 153. 
proposals, and thus, while it is formally an agenda-setter in the context of the EU legislative process, it is not a gatekeeper, since it is unable to keep items off the agenda. ${ }^{27}$ Although it is thus constrained in the making of substantive policy proposals, the Commission 'quite regularly'28 clashes with the Member States and also with the Parliament in making EU legislation, not least because their heterogeneity of preferences limits its ability to anticipate the eventual compromise position. In addition, other incentives are also seen as affecting its position, notably an 'entrepreneurial striving for more European integration and harmonization' in pursuit of an institutional interest to expand its competencies, budget and overall power in decision-making, similar to bureaucracies at the national level. ${ }^{29}$ Yet this 'invariant preference for more integration' 30 is unlikely to affect all policy areas to the same extent. More pertinent and more specifically predictive of the Commission's position on a topic such as the re-regulation of public procurement is the fact that, like the other main legislative EU institutions, the Commission - contrary to appearances - is not a unitary actor: power rivalries and diverging preferences among Commission Directorates General over 'appropriate regulatory goals' and the 'relative distribution of political and economic costs and benefits' can shape policy proposals, as can the responsible Commissioner's nationality. ${ }^{31}$

\section{B. Making EU Law - The Ordinary Legislative Procedure (OLP)}

The decisive feature of the OLP is that it formally puts the Parliament on an equal footing with the previously solely dominant Council in passing bills. First, the Commission drafts a legislative proposal - on its own initiative, at the request of other EU institutions ${ }^{32}$ or Member States, or

27 Thomson (fn. 10) 201; cf A Rasmussen, 'Challenging the Commission's Right of Initiative? Conditions for Institutional Change and Stability' (2007) 30(2) West European Politics 244; C Crombez, T Groseclose and K Krehbiel, 'Gatekeeping' (2006) 68(2) Journal of Politics 322.

28 Wonka (fn. 25) 100.

29 Wonka (fn. 25) 99. Cf, inter alia, B Hörl, A Warntjen and A Wonka, 'Built on Quicksand? A Decade of Procedural Spatial Models on EU Legislative Decision-Making' (2005) 12(3) Journal of European Public Policy 592-606.

30 Wonka (fn. 25) 99.

31 Ibid., 100.

32 The OLP may be launched at the request of the CJEU for a few, very specific purposes, such as establishing specialized courts attached to the General Court to hear at first instance particular types of proceedings in certain areas, as well as in line with Art. 13 of the CJEU Statute. 
because of a citizens' initiative, ${ }^{33}$ and normally following various forms of extensive internal and external consultation. The OLP formally begins when the proposed text is then forwarded simultaneously to the Parliament, Council and the national parliaments of the Member States ${ }^{34}$ as well as, in certain cases including the reform of public procurement, to the Committee of the Regions $(\mathrm{CoR})$ and the European Economic and Social Committee (EESC) for comment.

What follows are the first readings in the Parliament and the Council. In the case of the Parliament, its President forwards the proposal to the competent parliamentary committee (which in turn appoints a rapporteur) for the drafting of a report with potential amendments, on which it then votes. On this basis, the parliamentary plenary subsequently debates and votes on the legislative proposal under consideration; it may accept the proposal unchanged or amended (or ask the Commission to withdraw it): the result is its official first reading position, which is forwarded to the Council. The Council, meanwhile, has been undertaking its preparatory work, and its own first reading then happens based on the Parliament's finalized first reading position. If the Council accepts the Parliament's first reading position, the legislative act is adopted; if it elects to amend it, the Council's own first reading position is sent back to the Parliament for a second reading.

If either of the two main legislative institutions accepts the other's first reading position, the OLP can be concluded at this stage. If not, the Parliament is given three-four months to consider the Council's first reading position - again first in Committee for the preparation of a recommendation for the Parliament's second reading, upon which the plenary then votes, including on possible (limited) amendments. The legislative proposal is adopted in the Council's first reading version if the Parliament either approves it or fails to decide by the deadline; if the Parliament votes to reject it, the legislative proposal is not adopted and the procedure is closed.

If the Parliament adopts amendments to the Council's first reading position, this results in the Parliament's second reading position, which is forwarded to the Council for its second reading, for which there is also a three-four-month time limit. The proposed legislative act is adopted if the Council approves all parliamentary amendments in second reading. If

33 See contribution by Aspey to this book.

34 Under Protocols No 1 (role of national parliaments) and No 2 (principles of subsidiarity and proportionality) to the TEU, the Member State parliaments are (currently) given eight weeks to form a 'reasoned opinion' on whether the proposed draft legislation violates the subsidiarity principle. 
not, the Presidents of both institutions must, within six-eight weeks, jointly convene the Conciliation Committee, constituted by equal numbers of members of the Parliament and Council representatives. This Committee is given another six-eight weeks to agree on a joint text based on the Parliament's and the Council's second reading positions to be forwarded to both for a third reading; otherwise, the proposed legislative act is rejected and the OLP ends. In third reading, also limited to six-eight weeks, the co-legislators may decide in any order but may not change the proposed text. If both approve it in time, the legislative act is adopted; if not, it is rejected and the OLP is irrevocably concluded.

\section{Making EU Law - The Informal Trilogue}

Given the complexity and duration of this process, it is perhaps not surprising that early agreements (after first reading) have constituted a growing trend. In the case of the 2014 Public Procurement Package, too, the OLP was concluded early when the Council accepted the Parliament's position at first reading on February 11, 2014. ${ }^{35}$ Although there is no formal record of informal contacts, the speed with which the procedure was completed (barely a month after the Parliament had issued its first reading position) suggests that both institutions have availed themselves extensively of the informal practice of the inter-institutional trilogue with a view to facilitating the timely conclusion of the legislative process. In pursuit of a first reading agreement, the co-legislators often resort to such informal inter-institutional meetings, normally including the pertinent Parliament rapporteur, the Council Presidency representative in charge of the relevant working party and/or the permanent representative chairing COREPER, and Commission representatives from the responsible department as well as its Secretariat-General. The goal of these meetings, which have strongly increased over the last years, ${ }^{36}$ is to ensure that the Parliament's first reading position will be acceptable to the Council, with the Commission mediating and editing compromise texts. However, criticism has been levelled against the trilogues for their informality, lack of transparency, and potential for 'unwanted power redistributions within the institutions, ${ }^{37}$ to the advantage of the 'relais'

\footnotetext{
35 CS-PRES/2014/6328.

36 Naurin (fn. 13) 142.

37 See C Reh, 'Is Informal Politics Undemocratic? Trilogues, Early Agreements and the Selection Model of Representation' (2014) 21(6) Journal of European Public Policy 822. See also C Reh et al, 'The Informal Politics of Legislation. Explaining Secluded Decision Making in the European Union'
} 
actors' who represent them in those meetings and thus gain access to privileged information on the positions involved in the on-going legislative procedure. ${ }^{38}$ However, while there is some support for the notion of strengthened parliamentary rapporteurs, "so far no such evidence exists for the Council'. 39

\section{THE ROLE OF THE CJEU IN EU LAW-MAKING}

\section{A. The CJEU and the Construction of the EU Legal System ${ }^{40}$}

While the EU cannot be considered a state, and does not have a constitution, it does have a set of founding treaties, which the CJEU has described as a 'constitutional charter' ${ }^{41}$ Moreover, it has been undergoing what has been termed a process of 'gradual constitutionalization', in particular of its legal system. ${ }^{42}$ The CJEU has been playing a key role

(2013) 46(9) Comparative Political Studies 1112. See also GJ Brandsma, 'Co-decision after Lisbon: The Politics of Informal Trilogues in European Union Lawmaking' (2015) 16(2) European Union Politics 300.

38 Naurin (fn. 13) 142. Cf H Farrell and A Héritier, 'Interorganizational Negotiation and Intraorganizational Power in Shared Decision Making: Early Agreements under Codecision and Their Impact on the European Parliament and Council' (2004) 37(10) Comparative Political Studies 1184.

39 Naurin (fn. 13) 142. Cf F Häge and D Naurin, 'The Effect of Codecision on Council Decision-Making: Informalization, Politicization and Power' (2013) 20(7) Journal of European Public Policy 953.

40 Generally, on this topic, see RD Kelemen and SK Schmidt, 'Introduction - the European Court of Justice and Legal Integration: Perpetual Momentum?' (2012) 19(1) Journal of European Public Policy 1; SK Schmidt, 'Who Cares About Nationality? The Path-Dependent Case Law of the ECJ from Goods to Citizens' (2012) 19(1) Journal of European Public Policy 8; D Chalmers and M Chaves, 'The Reference Points of EU Judicial Politics' (2012) 19(1) Journal of European Public Policy 25; M Blauberger, 'With Luxembourg in Mind ... the Remaking of National Policies in the Face of ECJ Jurisprudence' (2012) 19(1) Journal of European Public Policy 109; and FW Scharpf, 'Perpetual Momentum: Directed and Unconstrained?' (2012) 19(1) Journal of European Public Policy 127.

41 Les Verts $v$ Parliament, C-294/83, EU:C:1986:166, cf Hix and Høyland (fn. 3) 83 .

42 Hix and Høyland (fn. 3) 83. Cf E Stein, 'Lawyers, Judges, and the Making of a Transnational Constitution' (1981) 75(1) The American Journal of International Law 1; JHH Weiler, 'The Transformation of Europe' (1991) 100(8) Yale Law Journal 2403; JHH Weiler, 'The Reformation of European Constitutionalism' (1997) 35(1) Journal of Common Market Studies 97. The rules of the 
in this process, helped by the fact that all EU Member States are by definition subject to the rule of law and their citizens accustomed to the idea of judicial hierarchy and a Court of last resort, which has increased acceptance of its decisions. Thus, the Court has been - and to the extent that the EU is permanently under construction, in the sense that adding to the acquis communautaire means continuing to build the system, (potentially) continues to be - instrumental in creating the very system that produces EU law, laying the foundations for its own influence on that system's output in the process. ${ }^{43}$ Most notably, in this context, it has established the quasi-federal doctrines of the direct effect and supremacy of EU law.

The direct effect of EU law, meaning EU citizens derive rights from it which must be upheld by national courts, was first established in a landmark ruling in 1963, against the resistance of the majority of Member States at the time. ${ }^{44}$ In it, the CJEU defined the EU as 'a new legal order' whose subjects were both the Member States and their citizens. Initially attributed to primary EU law (Treaty articles) only, the Court subsequently extended the doctrine of direct effect to all secondary EU legislation. ${ }^{45}$

internal market, in particular, have often been considered to be effectively of constitutional rank in discussions of their implications, $c f$, inter alia, ME Streit and W Mussler, 'The Economic Constitution of the European Community: From "Rome" to "Maastricht" (1995) 1(1) European Law Journal 5; W Sauter, Competition Law and Industrial Policy in the EU (Clarendon Press 1997); M Poiares Maduro, We the Court. The European Court of Justice and the European Economic Constitution. A Critical Reading of Article 30 of the EC Treaty (Hart Publishing, 1998); and J Baquero Cruz, Between Competition and Free Movement: The Economic Constitutional Law of the European Community (Hart Publishing, 2002).

43 For analyses of the Court's legal reasoning and the role of case law in the development of the EU acquis, $c f$, inter alia, G Beck, The Legal Reasoning of the Court of Justice of the EU, Modern Studies in European Law (Hart Publishing 2013) or, more critically, G Conway, The Limits of Legal Reasoning and the European Court of Justice, Cambridge Studies in European Law and Policy (Cambridge University Press 2014).

44 Van Gend en Loos v Nederlandse Administratie der Belastingen, C-26/62, EU:C:1963:1 ; cf Hix and Høyland (fn. 3) 84; Schmidt (fn. 1), 168; M Rasmussen, 'Revolutionizing European Law. A History of the Van Gen den Loos Judgment' (2014), 12(1) Int J Constitutional Law, 136-63; A Tizzano, J Kokott and S Prechal (eds), 50th Anniversary of the Judgment in Van Gend en Loos, 1963-2013 (EU Publications Office 2013).

45 Cf Stein (fn. 42), Schmidt (fn. 1) 169. 
Similarly, having asserted the supremacy of EU law in yet another landmark decision, ${ }^{46}$ the CJEU 'confirmed and reinforced [it] in subsequent rulings', 47 extending it to all forms of EU law. The linked federal principle of pre-emption, requiring lower political levels to cede their regulatory competence 'once an issue has been regulated at the higher level', has been 'much slower to develop' in the EU, ${ }^{48}$ counteracted not least by the principle of subsidiarity. ${ }^{49}$ However, the Court, having 'gradually developed a power to police the vertical allocation of competences' between the EU and its Member States, has been granted 'exclusive Kompetenz-Kompetenz' 50 by the Lisbon Treaty, which contains, for the first time, an explicit catalogue of competence distributions, which the CJEU now has 'the sole right to police':51 competences exclusive to the EU (Article 3 TFEU), shared between the EU and the Member States (Article 4 TFEU), areas where economic and social policies are to be coordinated (Article $5 \mathrm{TFEU}$ ), and areas where EU action may supplement that by Member States (Article 6 TFEU).

\section{B. The Role of the CJEU in EU Policy-Making}

Apart from its role in building the system, the CJEU plays an important part in shaping and implementing its legislative output. It does this in two main ways: one passive - enabling compliance with EU law, and one active - shaping EU law.

\section{Enabling compliance with EU law}

EU law takes three main forms. ${ }^{52}$ First, there are the primary acts negotiated among the EU Member States, i.e. the founding and successive reforming Treaties establishing and reforming the Union. Second, deriving from the Treaties, there are five types of secondary acts by the EU's legislative and executive institutions, i.e. the Council, the Parliament and the Commission; the most important of these are regulations

46 Costa v ENEL, C-6/64, EU:C:1964:66; cf Schmidt (fn. 1) 169.

47 Hix and Høyland (fn. 3) 85.

48 Schmidt (fn. 1) 168, $c f$ R Schütze, 'Supremacy without Pre-Emption? The Very Slowly Emergent Doctrine of Community Pre-Emption’ (2006) 43(4) Common Market Law Review 1023.

49 Art. 5 TEU. See G De Búrca, 'The Principle of Subsidiarity and the Court of Justice as an Institutional Actor' (1998) 36(2) Journal of Common Market Studies 217.

50 Hix and Høyland (fn. 3) 88-9.

51 Ibid., 89.

52 Ibid., 78-9. 
and directives. ${ }^{53}$ The distinction between them is no longer as clear-cut as may have originally been intended because directives often extend to a level of detail that does not allow for much leeway in transposition into national law. ${ }^{54}$ Moreover, both have direct effect, which is:

fundamentally important as it makes it more difficult for Member States to simply opt against compliance with non-implementation. Whereas before, Member States could only be targeted if the Commission initiated infringement procedures, with direct effect of directives, litigants can enforce their rights at their domestic courts, using 'fire alarm control' of insufficient implementation. .5

However, especially given the cases at hand in this book, it is important to note that there is a difference in the application of direct effect to regulations and directives. Having established the principle of horizontal, as opposed to just vertical, direct effect, ${ }^{56}$ the CJEU conferred both on regulations, while directives, due to the need for transposition, thus far have only vertical direct effect. ${ }^{57}$ Since affirming the direct effect of

53 Regulations are of general application, binding on the EU and all Member States, while directives are applicable to any or all Member States, binding in terms of the intended policy ends but not the means (i.e., to be transposed into national law). The remaining three types of secondary acts are decisions (applicable to Member States, EU citizens or legal entities, binding on addressees), recommendations (applicable to any or all Member States or EU citizens, not binding) and opinions (applicable to any or all Member States or EU citizens, not binding).

54 Hix and Høyland (fn. 3) 79. On the 'regulation-like' evolution of procurement directives see S Arrowsmith, 'The Past and Future Evolution of EC Public Procurement Law: From Framework to Common Code?' (2006) 35(3) Public Contract Law Journal 337. It could also be argued that more detailed directives enhance (vertical) direct effect.

55 Schmidt (fn. 1) 169, cf GF Mancini, 'The Making of a Constitution for Europe' (1989) 26(4) Common Market Law Review 595, 602. To the extent that the CJEU can be said to use secondary law to 'reinterpret' primary law, it is in a position to expand its powers such that direct effect for legal principles results via the detailed provisions of secondary acts; $c f$ S Treumer and E Werlauff, 'The Leverage Principle: Secondary Community Law as a Lever for the Development of Primary Community Law' (2003) 28(1) European Law Review 124.

56 Cf Walrave and Koch v Association Union Cycliste Internationale and Others, C-36/74, EU:C:1974:140; Defrenne v SABENA, C-43/75, EU:C:1976:56.

57 Cf Marshall $v$ Southampton and South-West Hampshire Area Health Authority, C-152/84, EU:C:1986:84; Faccini Dori $v$ Recreb, C-91/92, EU:C:1994:292. In any case, directives do have 'anticipatory direct effect', which prevents Member States taking any legislative action that counteracts a 
directives in $1974,{ }^{58}$ the CJEU has 'consistently denied' their horizontal direct effect; otherwise, the direct effect of all EU law is established 'as long as the criteria for direct effect are met: rules need to be clear and unambiguous; unconditional; and not requiring further action'.59 Arguably, this is more due to the political sensitivity of certain policy areas for Member States than any constitutional principle precluding it, as subsequently, to "compensate for the lack of a horizontal direct effect of directives', the CJEU established the "doctrine of "state liability", which the Member States had 'explicitly refused to grant' shortly before, ${ }^{60}$ and which 'implies that the state is liable for all infringements of EU directives' ${ }^{61}$

directive's objectives from the moment of its adoption, thus limiting their legislative discretion in anticipation of transposition; see Inter-Environnement Wallonie v Région wallonne, C-129/96, EU:C:1997:628; Mangold, C-144/04, EU:C:2005:709. 169.

58 Cf Van Duyn v Home Office, C-41/74, EU:C:1974:133; $c f$ Schmidt (fn. 1)

59 Schmidt (fn. 1) 170; $c f$ TC Hartley, The Foundations of European Union Law: An Introduction to the Constitutional and Administrative Law of the European Union (Oxford University Press 2010) 210; Stein (fn. 42).

60 Schmidt (fn. 1) 172.

61 Hix and Høyland (fn. 3) 84; cf. Francovich and Bonifaci v Italy, C-6/90 and C-9/90, EU:C:1991:428. This immediately after, 'in the Maastricht negotiations, Member States [had] explicitly denied granting the Court the right to order ... [them] to compensate private actors in preliminary rulings', and 'despite the criticism ... voiced against the Court at the time', Schmidt 2015: 172. Moreover, in the face of continued

strong member state opposition, the Court further elucidated the principle in a series of cases in 1996 (Brasserie du Pêcheur, Factortame III, British Telecommunications, Hedley Lomas, Dillenkofer). Following this, conditions are that the European law has to confer rights on individuals, the breach must be sufficiently serious, and there must be a causal link between the failure to comply and the loss suffered. The principle is relevant for all violations of European law, not only the non-transposition of directives but also irrespective of ... whether the law has direct effect.

(Schmidt (fn. 1) 172, cf. J Tallberg, 'Supranational Influence in EU Enforcement: The ECJ and the Principle of State Liability' (2000) 7(1) Journal of European Public Policy 104, 110.) The 'principle of indirect effect', requiring national courts to interpret national legislation consistently with EU law, completes the compensatory framework, cf Von Colson and Kamann $v$ Land NordrheinWestfalen, C-14/83, EU:C:1984:153. 
The third form of EU law are informal 'general principles of law ... derived from the EU's basic principles' 62 as expressed in primary law such as the preambles to the Treaties, or in the constitutions of the Member States. Four 'main types' of such 'general principles of law' can be distinguished:63

- 'principles of administrative and legislative legality', including legal certainty, proportionality and procedural fairness;

- 'economic freedoms', including the freedom of movement for goods, services, capital and persons as well as the freedoms of trade and competition; EU public procurement law has been considered as 'supplementing' these fundamental freedoms, which 'practically oblige Member States to create the Single Market via their sovereign responsibilities of public administration'; ${ }^{64}$

- 'fundamental human rights' as elaborated in the EU's Charter of Fundamental Rights;

- 'political rights' as declared by Member States and mentioned in the EU Treaty, including transparency and subsidiarity.

The CJEU is tasked by Article 19(1) TEU to 'ensure that in the interpretation and application of the Treaties the law is observed'. More specifically, the EU Treaty defines three main areas of CJEU jurisdiction for the purpose of fostering compliance with EU Law: infringement proceedings, judicial review and the preliminary references procedure. ${ }^{65}$

First, infringement proceedings may be brought against any EU Member State(s) for noncompliance with any part of the acquis communautaire by the Commission ${ }^{66}$ or by another Member State. ${ }^{67}$ The Treaty

\footnotetext{
62 Hix and Høyland (fn. 3) 79, emphasis added.

63 Ibid., 79.

64 W Hakenberg, Europarecht (7th edn, Vahlen 2015) 119-20; author's translation.

$65 C f$ Hix and Høyland (fn. 3) 82-3. The Court's jurisdiction also includes the more minor matters of suits for damages brought by Member States or private individuals against EU institutions (Art. 268 TFEU), European Council acts related to a member state's breach of fundamental rights (Art. 269 TFEU), and employment disputes between the EU and its staff (Art. 270 TFEU).

66 Art. 258 TFEU.

67 Art. 259 TFEU.
} 
explicitly makes compliance with the consequent CJEU ruling compulsory, ${ }^{68}$ and since the Treaty of Maastricht, this article empowers the Court to impose financial sanctions for non-compliance. ${ }^{69}$

Secondly, similar to constitutional courts at the national level, the CJEU has the power of judicial review of legislative and executive acts at the EU level, including those by the European Council and the European Central Bank (ECB). ${ }^{70}$ Pertinent actions can be brought by any Member State, the Council, the Parliament or the Commission on the grounds of 'lack of competence' or a violation of Treaty or procedural requirements; by the ECB, the Court of Auditors or the Committee of the Regions 'to protect their own prerogatives'; by private citizens against an EU institution's decision of 'direct concern' to them; or by 'any natural or legal person' 71 against an EU institution for failure to act despite having been tasked to do so under the acquis. ${ }^{72}$ In this context, '[p]recise rules, granting clear legal rights, favour ... "Eurolegalism", a variant of the adversarial legalism prominent in the US regulatory approach, as litigants find it then easier to push for implementation in their domestic courts' a type of 'fire alarm control' by private interests the Commission relies upon, and both the CJEU and the Parliament have pushed for, to foster compliance. ${ }^{73}$ Article 263 TFEU is particularly relevant in the area of public procurement carried out directly by EU institutions, and mainly the Commission: even if such procurement is not subject to the 2014 Public Procurement Package, the interpretation of the general procurement rules is influential for the CJEU's assessment of EU institutions' compliance with the applicable financial rules. Thus, in the area of public procurement, direct challenges of procurement decisions by EU institutions develop a function similar to that of preliminary references in challenges before Member States' domestic courts.

68 Art. 260 TFEU.

69 The post-Maastricht Art. 260 TEU allowed the Commission, 'in cases of perpetuated non-compliance to turn to the Court suggesting the payment of a lump sum or of a penalty', Schmidt (fn. 1) 171, provisions which were subsequently further strengthened both by the Court through case law and by the Member States in the Treaty of Lisbon (TFEU Art. 260(2) and (3)), cf. Schmidt (fn. 1) 171-2.

70 Art. 263 TFEU.

71 Hix and Høyland (fn. 3) 82.

72 Art. 265 TFEU.

73 Schmidt (fn. 1) 171; cf. R D Kelemen, Eurolegalism: The Transformation of Law and Regulation in the European Union (Harvard University Press 2011); MA Pollack, 'The New Institutionalism and EC Governance: The Promise and Limits of Institutional Analysis' (1996) 9(4) Governance 429. 
Third, under the preliminary references procedure, ${ }^{74}$ any national court may refer cases relating to any aspect of EU law to the CJEU for a preliminary ruling, while the highest national courts (those against whose decisions there is no appeal) must do so. While there is some national variation in terms of their incentives to do so, ${ }^{75}$ this option is generally attractive to national courts because basing their rulings on supreme EU law can help to protect them against being overturned in the national judicial hierarchy. ${ }^{76}$

While national courts then have 'some discretion' in applying the CJEU's preliminary rulings in their own judgments, those preliminary CJEU interpretations of EU law often allow little leeway. ${ }^{77}$ Thus, rather than leaving the final ruling on such cases to national courts, as the procedure - and in particular its designation as 'preliminary' - might suggest, it not only 'reveals a high penetration of EU law into the national legal systems', but, 'by enabling national courts to enforce ... [CJEU] judgments', effectively turns them into 'the lower tier of an integrated EU court system, and the ... [CJEU into] the quasi-supreme court at its pinnacle.' 78 This means Member States cannot ignore EU law

74 Art. 267 TFEU.

75 Cf J Golub, 'The Politics of Judicial Discretion: Rethinking the Interaction Between National Courts and the European Court of Justice' (1996) 19(2) West European Politics 360; M Wind, 'The Nordics, the EU and the Reluctance Towards Supranational Judicial Review' (2010) 48(4) Journal of Common Market Studies 1039.

76 Cf JHH Weiler, 'A Quiet Revolution: The European Court of Justice and Its Interlocutors' (1994) 26(4) Comparative Political Studies 510, 518-20; Schmidt (fn. 1) 164; KJ Alter, Establishing the Supremacy of European Law. The Making of an International Rule of Law in Europe (Oxford University Press 2006). See also ibid., The European Court's Political Power. Selected Essays (Oxford University Press 2009).

77 Hix and Høyland (fn. 3) 82-3.

78 Ibid., 83. Not all national courts of the Member States would consent to being considered 'lower' in the EU's judicial hierarchy, however ( $c f$ W Mattli and A-M Slaughter, 'Revisiting the European Court of Justice' (1998) 52(01) International Organization 177). In particular, a constitutional court like the German Bundesverfassungsgericht, quite used to having the final say, has in the past insisted on its 'highest Court' status by inserting a proviso of future constitutionality (particularly with respect to human rights and national identity) into rulings upholding EU law and CJEU judgments and by reserving the right to declare acts of EU organs ultra vires (e.g. in the German Court's Brunner decision on the Maastricht Treaty, or its 2009 Lisbon ruling), cf. Alter (2006, fn. 76), Hix and Høyland (fn. 3), JH Weiler, 'Does Europe Need a Constitution? Demos, Telos and the German Maastricht Decision' (1995) 1(3) European Law 
without destabilizing their domestic judicial systems. ${ }^{79}$ Thus, given that rulings under the preliminary references procedure now constitute 'the majority' of CJEU judgments, its jurisdiction under Article 267 TFEU has proved 'far more significant for the development of EU law and the constitutionalization of the EU system' than that in any other domain of law. ${ }^{80}$

In sum, the CJEU plays 'the traditional role of courts in policymaking, a passive, enabling role, fostering compliance' and thus strengthening the rule of law and the actors' confidence 'that agreements are kept and policies implemented, despite incentives to defect' ${ }^{81}$ The CJEU acts, in other words, as the final guarantor of credible - and, for secondary legislation, 'unprecedented' 82 - commitment, tying both Member States and the representatives of the European public to their own ideals as expressed, not least, in the preambles of successive Treaties. The EU's overall compliance record demonstrates the CJEU's effectiveness in this regard, ${ }^{83}$ due not least to the somewhat 'unexpected development of judicial enforcement', bolstered by the expansion of direct effect and 'the broad indirect access' allowed by the preliminary references procedure, as both it and the infringement procedure 'acquired more teeth' over time. ${ }^{84}$

Journal 219; Schmidt (fn. 1) 164/165. Similarly, the highest national courts in the UK and France have maintained that the acceptance of the supremacy and direct effect of EU law 'is conditional on national constitutional norms: for example that parliaments retain the right to revoke the supremacy of EU law by withdrawing the transfer of sovereignty to the EU', Hix and Høyland (fn. 3) 95, something that the House of Commons has reaffirmed intermittently.

79 Cf. Schmidt (fn. 1) 164.

80 Hix and Høyland (fn. 3) 82-3; cf. the Annual Reports of the CJEU, Schmidt (fn. 1) 163.

81 Schmidt (fn. 1) 170.

82 Ibid., 160.

83 Cf. Hix and Høyland (fn. 3) 100; M Zürn and D Wolf, 'Europarecht und Internationale Regime: $\mathrm{Zu}$ den Merkmalen von Recht Jenseits des Nationalstaates', in E Grande and M Jachtenfuchs (eds), Wie Problemlösungsfähig ist die EU? Regieren im europäischen Mehrebenensystem (Nomos 2000) 113. This with the obvious, major proviso that the Court and all other EU institutions continue to rely almost entirely on the Member States' national resources for law enforcement.

84 Schmidt (fn. 1) 170. 


\section{Shaping EU law}

The relative dearth of analyses of the precise impact of case law on EU legislative decision-making, or of how EU Member States and legislative institutions have dealt with the fact that case law, as 'an alternative to secondary law' 85 constrains legislative options, means that the CJEU's weight in EU policy-making is 'both well recognized and misconceived' ${ }^{86}$

Political science does offer a range of models to explain 'the strategic interaction between legislators and judges' 87 more broadly, and the 'central result' of the work on courts is that they are 'powerful and essentially weak actors at the same time' ${ }^{88}$ The CJEU displays the reasons for this very well: its power results from its potential role as a veto player in the policy process and its entrenched 'constitutional' position; its weakness from its relative passivity, its dependence on being called upon to rule in the first place (i.e., being brought cases) by other players in the policy process, as well as on those other players' subsequent compliance with its rulings.

After early work from what has been described as a 'legal-formalist' perspective saw the CJEU mainly as 'a heroic promoter of European integration against the wishes of the Member States', ${ }^{89}$ two main competing approaches have established themselves. 90

2.1 The intergovernmentalist perspective and the importance of Member State preferences The intergovernmentalist school of European integration sees the CJEU merely as an 'agent' of the EU Member States, 'empowered to enforce integration' on their behalf but reined in by the judges' status as 'national delegates' and by the twin threats of noncompliance and sanctions if it exceeds its mandate. ${ }^{91}$ However, Member

85 Ibid., 174.

86 Ibid., 160.

87 Hix and Høyland (fn. 3) 75-6.

88 Schmidt (fn. 1) 160.

89 Hix and Høyland (fn. 3) 95-6; $c f$ Weiler (fn. 76).

90 Cf. KJ Alter, 'The European Court and Legal Integration. An Exceptional Story or Harbinger of the Future?', in KE Whittington, RD Kelemen and GA Caldeira (eds), The Oxford Handbook of Law and Politics (Oxford University Press 2008) 209.

91 Hix and Høyland (fn. 3) 95, cf 97-8; G Garrett, RD Kelemen, and H Schulz, 'The European Court of Justice, National Governments, and Legal Integration in the European Union' (1998) 52(1) International Organization 149; RD Kelemen, 'The Limits of Judicial Power: Trade-Environment Disputes in the GATT/WTO and the EU' (2001) 34(6) Comparative Political Studies 622. 
States' possibilities for both noncompliance (as discussed in part III.B.1 above) and sanctions (see point III.B.3.4 below) are quite limited. What is more, the empirical answer to the key question of how much the CJEU's judgments reflect (in particular: large) Member States' preferences appears to be: not very much, as the evidence suggests that the CJEU has 'often' ruled against their submitted opinions, observations or stated policies: ${ }^{92}$

It is not uncommon for the Court to interpret secondary law in the light of [T]reaty provisions, thereby coming to interpretations that deviate from the express meaning of the legislation, or to read precise obligations out of the [T]reaty, so that Member States have to enact steps also when there is no agreement on secondary law ... The fact that case law often merely works to favour one legislative actor over another may be taken to deny its independent relevance ... However, it has to be recognized that there would not have been a political agreement on this precise judicial interpretation, which favours one interpretation at the costs of others. ${ }^{93}$

In order to square this with a view of the CJEU as a compliant agent of powerful Member State principals, it would be necessary to accept the judges' majority view as an 'imperfect proxy' for the majority view of the Member States who appointed them. ${ }^{94}$ In addition, claims about the direct or indirect (via the selection of judges, see point III.B.3.2 below) impact of Member State preferences at least implicitly - and wrongly -

92 Schmidt (fn. 1) 161-2; cf M-P Granger, 'When Governments Go to Luxembourg ... The Influence of Governments on the European Court of Justice' (2004) 29(1) European Law Review 3; RA Cichowski, 'Courts, Rights, and Democratic Participation' (2006) 39(1) Comparative Political Studies 50. Yet, according to Hix and Høyland (fn. 3) 99, research has also shown that CJEU 'activism ... has not been linear' ( $c f$ D Chalmers, 'Judicial Preferences and the Community Legal Order' (1997) 60(2) Modern Law Review 164) but has 'responded to the pace of the integration process' and been 'sensitive' to Member States' preferences and concerns vis-à-vis the Court ( $c f$ CJ Carrubba, M Gabel and C Hankla, 'Judicial Behavior under Political Constraints: Evidence from the European Court of Justice' (2008) 102(4) American Political Science Review 435).

Schmidt (fn. 1) 162.

94 M Malecki, 'Do ECJ Judges All Speak with the Same Voice? Evidence of Divergent Preferences from the Judgments of Chambers' (2012) 19(1) Journal of European Public Policy 59, 62. 
'assume a perfect malleability of law, which judges can interpret according to political need' ${ }^{95}$

\subsection{The supranationalist perspective and the importance of case law} The supranationalist school of European integration, by contrast, points out that as more and more different actors gain access to the EU policy process in a variety of ways, 'leading to shifting coalitions', Member States have lost their position as 'gatekeepers, channelling input into the supranational system' ${ }^{96}$ In this view, the CJEU is an independent-minded policy entrepreneur capable of working with 'self-interested lower national courts, integrationist judges, and private interests to move EU integration beyond the intentions of the governments'. ${ }^{97}$ In this, the Commission is an 'important ally' of the CJEU: its ability to initiate cases means it is 'well poised to strategically influence the development of case law', and it 'normally' contributes observations to all cases where it is not party to the proceedings; in fact, its 'policy position is a good predictor of the case outcome as it is normally on the winning side'.$^{98}$

Thus, in the EU, 'to an extent more known from the US than from European countries, litigation has ... become an alternative to lobbying as legal changes can be realized via case law or via secondary law'. ${ }^{99}$ Because secondary EU law 'is often equivocal and loosely worded', 100 quite deliberately allowing different interpretations of what compliance would require from the perspective of Member States, the CJEU has been seeking definite readings:

Even where a directive is ambiguously formulated, the Court will not take the view that what one might call different interpretations may coexist. Instead the Court will determine the one and only correct interpretation, leaving little or no discretion to the national legislature. ... [T] his non-deferential approach

95 Schmidt (fn. 1) 166. Given the intransparency of the CJEU's votes and the absence of dissenting opinions, an empirical analysis of this question remains impossible, however.

96 Schmidt (fn. 1) 166.

97 Hix and Høyland (fn. 3) 95, cf 98-100, Alter (fn. 90).

98 Schmidt (fn. 1) 166, Cichowski (fn. 92) 499.

99 Schmidt (fn. 1) 166; cf $\mathrm{P}$ Bouwen and M McCown, 'Lobbying Versus Litigation: Political and Legal Strategies of Interest Representation in the European Union' (2007) 14(3) Journal of European Public Policy 422; JA Caporaso and S Tarrow, 'Polanyi in Brussels: Supranational Institutions and the Transnational Embedding of Markets' (2009), 63(04) International Organization 593; Kelemen (fn. 73).

100 Schmidt (fn. 1) 170. 
puts a considerable burden on the Court, and may indeed lead it to fill in significant gaps in the text of the [Union] legislation which ... is often the result of compromise and may therefore be unclear on crucial policy issues. ${ }^{101}$

In this way, case law becomes 'an alternative to secondary law', and whether 'existing or pending' - must be taken into account in the analysis of EU decision-making alongside the preferences of the Member States and the legislative institutions, 'as the default condition of decisionmaking is shaped judicially'. ${ }^{102}$

\section{Limiting the CJEU's influence?}

The question arises what, if any, limits are there to the discretion and influence of the CJEU? Pertinent in this context is work straddling the boundaries between political science and law that has identified a series of factors affecting the extent of a court's discretion, most of them applicable to the CJEU.

3.1 Repeals and circumventions First, there is the possibility of active resistance to CJEU decisions and the question of the probability of new legislation repealing or effectively circumventing CJEU decisions. Some scholars consider the probability of repeals to be $l_{0 w}^{103}$ due to the involvement of veto-players able to prevent such changes. ${ }^{104}$ Given that law normally represents 'compromises among political actors' who 'may interpret these compromises differently'; and because the Court's interpretation 'is likely to favour one party over the other', it may be 'difficult to muster the necessary majority to intervene against the case law'.105 This is especially likely in 'separation-of-powers systems' like the EU, where, furthermore, 'legislation must be adopted by oversized and

101 P Eeckhout and T Tridimas, 'The European Court of Justice and the Legislature' in P Eeckhout and T Tridimas (eds), Yearbook of European Law (Oxford University Press 1998) 1, 8.

102 Schmidt (fn. 1) 174; cf SK Schmidt, 'Only an Agenda Setter? The European Commission's Power over the Council of Ministers' (2000) 1(1) European Union Politics 37.

103 Cf JA Ferejohn and BR Weingast, 'A Positive Theory of Statutory Interpretation' (1992) 12(2) International Review of Law and Economics 263; G Vanberg, 'Abstract Judicial Review, Legislative Bargaining, and Policy Compromise' (1998) 10(3) Journal of Theoretical Politics 299.

$104 C f$ Hix and Høyland (fn. 3) 76-7; G Tsebelis, 'Veto Players and Institutional Analysis' (2000) 13(4) Governance 441; G Tsebelis, Veto Players. How Political Institutions Work (Princeton University Press 2002).

105 Schmidt (fn. 1) 161. 
multiple legislative majorities', so that the CJEU can 'reasonably assume that at least one veto-player will prefer the court's interpretation to the original legislative intention, and hence block a repeal of the court's decision'. ${ }^{106}$

On the other hand, while the EU legislative can thus be seen as operating in 'the shadow of case law', ${ }^{107}$ it makes 'a great difference' whether the case law in question relates to primary or secondary EU law, given that the latter is easier to adjust and hence 'less of a constraint'. Between the two extremes of either having no influence or replacing legislation ('in the sense of making it superfluous or overruling it'), case law may 'motivate legislation' in two different ways: ${ }^{108}$ Member States may seek to codify it to make it 'more accessible' for market participants and to further legal certainty and equality before the law; or they may seek to 'pre-empt it' by passing legislation that represents a 'lesser evil'.109 While perhaps not a priority for Member States, or even unwanted, such legislation may help them retain regulatory control when confronted with emerging case law the thrust of which they disagree with. A third way for Member States to resist unwanted case law, provided the necessary majorities are available, is to adopt secondary legislation that deviates from the case law in question openly (as in the case of public procurement, as further discussed in several of the contributions to this book and in the conclusions), or to circumvent such case law by nominally consolidating or codifying it in new legislation which effectively restricts it. ${ }^{110}$

3.2 Disunity and uncertainty Second, there is the question of legislators' awareness of the Court's preferences - and the related issue of whether any assessment of the CJEU's role in the context of EU decision-making, or of its likely decisions, can justifiably proceed from the assumption that the Court is a unitary actor. Given that there are bound to be variations in preferences among the judges and advocates general as to their rulings' political and policy impact, 'the composition

\footnotetext{
106 Hix and Høyland (fn. 3) 77.

107 Schmidt (fn. 1) 174; cf Schmidt (fn. 102).

108 Schmidt (fn. 1) 174-6.

109 Schmidt (fn. 102).

110 One case where a majority of Member States have acted to restrict the impact of CJEU case law is the adoption of the 'Citizens Rights Directive' (2004/38/EC), which was contrary to it. Cf M Dougan, 'The Constitutional Dimension to the Case Law on Union Citizenship' (2006) Inter Alia: University of Durham Student Law Journal 77, 79.
} 
of the court matters'. ${ }^{111}$ Can the Member States influence the Court's position by packing the bench in their favour via the appointment of the judges ${ }^{112}$ - one from each Member State?

Formally, the judges' independence must be 'beyond doubt' and they must 'possess the qualifications required for appointment to the highest judicial offices in their respective countries' ${ }^{113}$ - suitability criteria which the contracting parties felt it necessary to reinforce in the Lisbon Treaty via the introduction of a vetting of candidates by a panel of former CJEU judges and national courts. ${ }^{114}$ The Treaty also specifies that judges and advocates general 'shall be appointed by common accord of the governments of the Member States for a term of six years', with 'a partial replacement' of both every three years. ${ }^{115}$ While staggering the judges' tenure is intended to ensure continuity, ${ }^{116}$ in practice, this means that Member States propose one judge each, and their nominations are then ratified on a quid pro quo basis. ${ }^{117}$ Concerns about undue national influence on judicial opinions may be heightened further by the facts that the judges' terms are renewable - which may open them to political pressure - and that their votes are always secret, their deliberations not even recorded and no dissenting opinions published. Still, the latter has also been seen as shielding the judges from such pressure, and, given decision-making by simple majority in the CJEU's chambers, a judge would have to hold the median position in order to make a difference, which may be quite unlikely. ${ }^{118}$

The reigning uncertainty cuts both ways, however: just as the Member States may not be entirely sure of the judging majority's preferences, the CJEU has 'imperfect information' 119 about stakeholders' likely reactions to its decisions, and, due to the 'heterogeneous' institutional context in which it operates, 'it cannot foresee all implications of its rulings'. ${ }^{120}$ While Member State governments' 'shorter time horizons' (due to their

111 Hix and Høyland (fn. 3) 77.

112 Cf. RD Kelemen, 'The Political Foundations of Judicial Independence in the European Union' (2012) 19(1) Journal of European Public Policy 43.

113 Art. 253 TFEU.

114 Art. 255 TFEU, $c f$ Hix and Høyland (fn. 3) 79-80.

115 Art. 253 TFEU.

$116 C f$ Hix and Høyland (fn. 3) 80.

117 In addition, the large Member States conventionally appoint one advocate general each, while the remainder of positions rotates among the smaller ones, $c f$ Hix and Høyland (fn. 3) 80.

118 Cf Kelemen (fn. 112), Schmidt (fn. 1) 162-3.

119 Hix and Høyland (fn. 3) 100.

120 Schmidt (fn. 1) 167. 
limited political life) make them 'less interested in the long-term implications of delegating powers' to the Court than in 'the immediate political salience of a decision', the latter is also harder to predict for the CJEU, especially across 28 Member States. ${ }^{121}$ While this means that 'the outcome of activist case law does not require an activist court', ${ }^{122}$ an 'often-noted strategy of the Court' has been to 'develop case law incrementally, ... initiating new developments in cases of little relevance, so as to avoid immediate Member States' opposition. ... Once politically more contentious cases arise, the case law is already more settled, constraining political influence'. ${ }^{123}$

Overall, as 'the ease of adopting new legislation and acquiring information about the likely action of the court goes up, the discretion of the court goes down', which implies that the CJEU had the most 'potential power' earlier in the process of European integration ${ }^{124}$ - an assessment that seems to be supported by the timing of the CJEU's early landmark decisions establishing the principles of the direct effect and supremacy of EU law in the 1960s, as well as by that of its kick-start to the internal market with the decision on the principle of mutual recognition in $1979 .{ }^{125}$

\subsection{Opportunity and cooperation A third factor affecting the extent} of the CJEU's discretion is what opportunities it gets to pursue its preferences by handling pertinent cases: ${ }^{126}$ in principle, 'courts are politically weak as they rely on being called on to decide cases and on being followed in their judgments'. ${ }^{127}$ The CJEU's ability to act depends not least on the cooperation of national courts, who themselves exercise considerable discretion - and may act with a variety of motives - in terms of what to refer to the CJEU in the context of the preliminary

\footnotetext{
121 Hix and Høyland (fn. 3) 100/101, cf. Schmidt (fn. 1) 166.

122 Schmidt (fn. 1) 167.

123 Ibid.; $c f$ KJ Alter (fn. 76), and ibid, 'Who Are the 'Masters of the Treaty'?
} European Governments and the European Court of Justice' (1998) 52(2) International Organization 121, 131.

124 Hix and Høyland (fn. 3) 76-7.

125 This in the famous Rewe $v$ Bundesmonopolverwaltung für Branntwein (Cassis de Dijon), C-120/78, EU:C:1979:42.

$126 C f$ Alter (fn. 90); JR Rogers, 'Information and Judicial Review: A Signalling Game of Legislative-Judicial Interaction' (2001) 45(1) American Journal of Political Science 84; JR Rogers and G Vanberg, 'Judicial Advisory Opinions and Legislative Outcomes in Comparative Perspective' (2002) 46(2) American Journal of Political Science 379.

127 Schmidt (fn. 1) 161. 
references procedure; ${ }^{128}$ and on incentivized private actors such as firms and interest groups with the 'resources to take actions all the way through' to the CJEU. ${ }^{129}$ For the CJEU to exercise its full potential influence, there 'needs to be a sufficient case load to develop case law, precedent needs to be honoured, and reasons given, allowing litigants to draw on case law to further their interests'. ${ }^{130}$

Linked to the opportunity factor is the issue of the Court's increasingly overwhelming workload, ${ }^{131}$ the impact of which is not entirely clear, however: delayed decisions may affect the parties to a dispute in different ways, but are unlikely to systematically favour any of them, whether institutions, Member States or other litigants. There may be more room for the CJEU to prioritize some decisions over others; however, once again the consequences are uncertain. Various measures intended to address the increased workload, such as the introduction of the Court of First Instance (CFI) in 1989 (now the General Court, GC), the shifting of a majority of cases to Chambers of three or five judges, the 2012/2013 review of procedural rules and the 2015 expansion of the CJEU, have ameliorated its ability to cope. However, the fact that up to 90 per cent of cases are now heard by the smaller chambers 'may, to the extent that

128 Cf. Hix and Høyland (fn. 3) 99; KJ Alter, 'The European Court's Political Power' (1996) 19(3) West European Politics 458; Alter (fn. 76); Golub (fn. 75); Schmidt (fn. 1); AS Sweet and TL Brunell, 'The European Court and the National Courts: A Statistical Analysis of Preliminary References, 1961-1995' (1998) 5(1) Journal of European Public Policy 66; Weiler (fn. 42) 73. The national courts' discretion is underlined by the fact that the CJEU has seen fit to pursue a line of case law enabling it, through the invocation of state liability, to discipline even the highest national courts where they have refrained from referring pertinent questions, cf. e.g. Köbler, C-224/01, EU:C: 2003:513; Traghetti del Mediterraneo, C-173/03, EU:C:2006:391.

129 Hix and Høyland (fn. 3) 99; cf Alter (fn. 90); LJ Conant, Justice Contained: Law and Politics in the European Union (Cornell University Press 2002); but also MA Pollack, 'Representing Diffuse Interests in EC PolicyMaking' (1997) 4(4) Journal of European Public Policy 572.

130 Hix and Høyland (fn. 3) 99.

131 As of December 31, 2014, the CJEU has delivered more than 30,000 judgments (since 1952). It is noteworthy, however, that in the most recent year reported, 2014, only the Court of Justice managed to close more cases than were introduced, while the General Court and the Civil Service Tribunal did not. Moreover, it was only the second time since 2006 the Court of Justice achieved this, having (just) broken even in 2013. As a result, it has been continually carrying a load of pending cases fluctuating between 600 and almost 1000, cf. the CJEU Annual Reports. 
there is variation in the opinion of judges, decrease the predictability' of the Court's rulings again. ${ }^{132}$

3.4 Sanctions Finally, the CJEU's discretion may be limited to the extent that the Member States can credibly threaten and effectively impose sanctions on it. In theory, if its rulings became 'politically too contentious', the CJEU might 'risk changes in ... [its] institutional foundations'. ${ }^{133}$ However, in practice, 'court-curbing mechanisms' such as removing CJEU competences or resources or even changing its mandate are subject to the 'joint decision-trap': ${ }^{134}$ the difficulty to achieve the required unanimous agreement of all Member States protects the CJEU's position, and so there is just 'a small probability' of Treaty change for the purpose of reigning in the CJEU. ${ }^{135}$ Hence, 'jurisdiction stripping has never occurred retroactively', 136 even though the (initial) retention of certain policy areas (e.g. immigration and asylum before Maastricht) beyond the CJEU's jurisdiction could be seen as an indicator of Member States' wariness of the irrevocability and consequences of the CJEU's taking possession of sensitive policy areas. ${ }^{137}$

\section{CONCLUSIONS}

All institutions contributing to the making of EU law bring distinctive incentives and constraints to that process. Its combination of complexity, multiple and varied links among the participants and the potential for cross-issue linkages has led to the supplementation of the formal legislative procedure with informal elements, most notably the trilogue between Council, Parliament and Commission. Against this background, the CJEU plays a deeply entrenched part in the context of EU decisionmaking in terms of polity-construction, shaping EU law and fostering compliance with it. Although certain factors may limit its discretion, their

\footnotetext{
132 Hix and Høyland (fn. 3) 81, $c f$ the above discussion of uncertainty under point II.B.3.2.

133 Schmidt (fn. 1) 161.

134 Cf FW Scharpf, 'The Joint-Decision Trap Revisited' (2006) 44(4) Journal of Common Market Studies 845.

135 Hix and Høyland (fn. 3) 100.

136 Schmidt (fn. 1) 163.

137 Cf. Kelemen (fn. 112); Schmidt (fn. 1). One important policy area in which the CJEU may be observed to be exercising self-restraint in order to avoid such Treaty reforms is that of citizenship, cf Dano, C-333/13, EU:C:2014:2358. Very recently, see also García-Nieto and Others, C-299/14, EU:C:2016:114.
} 
cumulative impact is not unequivocal. Meanwhile, with the expansion of EU competence into ever-widening policy fields, EU law has come to apply to almost all policy domains, and additional case law continues to consolidate the reach of the CJEU, for example in terms of the protection of fundamental individual rights. ${ }^{138}$

The CJEU, therefore, has had, and continues to have, a considerable substantive impact on the development of EU legislation over time. In particular, the direct effect and supremacy of EU law has allowed it 'to play a central role in the economic and political integration of the EU', ${ }^{139}$ and to shape political choices via rulings in pertinent cases. In this way, CJEU case law gave 'an important impetus' to the completion of the single market, and the 'same can be said for the equality of treatment of women and anti-discrimination policies in general'. ${ }^{140}$ Indeed, the combined effect of the Dassonville ${ }^{141}$ and Cassis de Dijon ${ }^{142}$ judgments (plus related cases), on the freedom and competitiveness of intra-EU trade and the principle of mutual recognition, has been seen to amount to an 'inherently deregulatory' interpretation of primary EU law, overriding long-standing 'social, cultural and ideological preferences' 143 of Member States and other stake-holders. This has resulted in considerable political controversy, earning praise from advocates of a free internal market and scorn from critics of the EU's alleged neo-liberal agenda. ${ }^{144}$ Similarly, the reforms of EU public procurement law are shaped by the competing and potentially contradictory aims of clarification and homogenization (equality of opportunity and treatment) on the one hand, and flexibility and market-orientation on the other hand - in addition to the everpervasive conflict dimension underlying all EU decision-making: the tension between Member State national autonomy and the authority of the Union. ${ }^{145}$ The CJEU's substantive impact on EU law, in other words, can trigger significant political backlash.

138 Cf. Schmidt (fn. 1) 168; Hix and Høyland (fn. 3) 85; Stein (fn. 42); G Davies, 'Activism Relocated. The Self-Restraint of the European Court of Justice in Its National Context' (2012) 19(1) Journal of European Public Policy 76.

139 Hix and Høyland (fn. 3) 86.

140 Schmidt (fn. 1) 173.

141 Dassonville, C-8/74, EU:C:1974:82.

142 See above (fn. 129).

143 Hix and Høyland (fn. 3) 86.

$144 C f$ Kelemen (fn. 73); Schmidt (fn. 1) 165 and P Kunzlik, 'Neoliberalism and the European Public Procurement Regime (2013)' 15 Cambridge Yearbook of European legal studies 283, on procurement in particular.

145 For discussion in the area of public procurement, see S Arrowsmith, 'The Purpose of the EU Procurement Directives: Ends, Means and the Implications for 
The EU Member States have been trying to re-assert regulatory control by strengthening the position of the European Council and maintaining the pre-eminence of the ministerial Council's legislative role, while the Parliament is generally acknowledged to have been empowered over time (most visibly through the codification of the OLP as the default approach to EU law-making), albeit not quite to equality with the Council. Both are powerful players, and the CJEU has been faced with the task of reining them in order to balance the long-term Union interest against the more short-term preferences of Member State governments on the one hand, and directly elected members of Parliament and their party groups on the other.

The way and extent to which the CJEU has been able to achieve this task demonstrates that the benefit of the CJEU 'in terms of a strengthened obligation attached to agreements' comes at the 'significant cost of a weak legislature being unable to counter unwanted case law developments'; indeed, the example of the CJEU demonstrates that 'Courts beyond the nation-state ... can surpass national constitutional courts in political significance'. ${ }^{146}$ The Member States and the other EU institutions have contributed to this steady increase in self-commitment: by perfecting the art of framing new legislation in language open enough to be agreeable to all, they facilitate political compromise based on language changes that may not have any legal implications. Overall, the Court is 'a powerful constitutional and administrative body to oversee the implementation of EU law and keep the EU institutions in check', with 'substantial room for manoeuvre': ${ }^{147}$ its political significance is the price EU Member States 'have to pay for the benefits of an independent judiciary'. ${ }^{148}$

National Regulatory Space for Commercial and Horizontal Procurement Policies' (2012) 14 Cambridge Yearbook of European Legal Studies 1.

146 Schmidt (fn. 1) 160.

147 Hix and Høyland (fn. 3) 100.

148 Schmidt (fn. 1) 162. 